\title{
IMPACT OF PRICE-DEREGULATION ON MARKET OUTCOMES - THE CASE OF CHIMNEY SWEEP SERVICES IN SLOVENIA
}

\author{
Egon Žižmond*, Matjaž Novak**
}

\begin{abstract}
:
In transition countries, especially in the period of central planning or semi-command regulation, prices of goods and services in the non-tradable sector were regulated, which was one of the main obstacles to normal functioning of the supply-demand market mechanism after the breakdown of the socialist economic system. In the period of economic transition reestablishment of market institutions arises, with price deregulation as one of the fundamental constitutional parts of this process. But in the case of transition economies there exists a recognized doubt in an immediately well functioning market system after deregulation because of inadequate development of the economic system in the past that produced a gap in the development of institutions typical for market economies.

The aim of this article is to present the results of the empirical analysis on the market outcomes of price deregulation for chimney sweep services in the Slovenian economy. For this purpose we developed an original model for analysing market outcomes after price deregulation occurs. For the selected case study we recognize large cumulative price growth, that was a consequence of significant supply-side imperfection, since the selection among suppliers is based on the concession system at the municipality level.
\end{abstract}

Keywords: Inflation inertia, non-tradable sector, technical efficiency, transition, costs, technical coefficient, market competitiveness, Slovenia

JEL Classification: D, D4, D43

\section{Introduction}

Price deregulation is a constitutional part of reforms that took place during the transitional period in transition economies, since the price mechanism is one of the core pillars of a well functioning market system.

The main problem of price deregulation in transition economies was the potential impact on inflation and hence on macroeconomic stabilisation. Especially problematic was the deregulation of prices in the non-tradable sector that was not con-

\footnotetext{
*) University of Primorska, Faculty of Management Koper, Slovenia.

**) University of Primorska, Faculty of Management Koper, Slovenia.
} 
fronted with rising foreign competition pressure and forms of oligopoly or perhaps even monopoly market structure. That was one of the main reasons why some prices in the non-tradable sector remained under government regulation during the transition period. But to successfully conclude the process of transition and, in case of eight advanced transition countries, ${ }^{1}$ also to fulfil the requirements of the EU for joining the Union in May 2004, full price deregulation was required, which has influenced the rise of new forms of inflation inertia.

From this point of view the mentioned transition countries faced a specific problem: on the one hand the liberalisation of all prices that were not regulated in the EU was necessary, but on the other hand the existing market structure for goods and services with regulated prices was not able to ensure good functioning of the supply-demand mechanism.

Irrespective of these facts the advanced transition countries continue with price deregulation aimed at fulfilling criteria for joining the EU and EMU, although the possible market outcomes could be negative and would not lead to price stabilisation. Henceforth price deregulation raises the need to analyse its impacts and market outcomes. Especially interesting is the issue of to what extent market outcomes after price deregulation coincide with outcomes that are significant for a well functioning market system.

For this purpose we developed an original model for analysing the impact of price deregulation on market outcomes. In this article we briefly present its structure upgraded with an empirical example about the market outcomes in the case of chimney sweep services in Slovenia after price deregulation. Following these aims, the article is divided into five parts. We start with development of the theoretical and systemic origins for analysing the impact of price deregulation on market structure in the first and second chapter. Third, the methodological framework is developed. Fourth, the results of empirical analysis on the impact of price deregulation are described. Finally the article summarises the main findings and concludes with a discussion on the economic policy implications.

\section{Systemic Origins of Price Deregulation in Transition Economies}

Following the route of modern neoclassical economic theory, the introduction of the market system (which includes also liberalisation of prices) in transition economies should lead to the destruction of inflation mechanisms, stabilize the price movements and accelerate the market competition. This is also the basic idea behind the efforts of the European Union to reestablish a well functioning free-market economic system that should stimulate market competition aimed at stabilising overshooting price movements.

But in the case of transition economies there exists a recognized doubt in an immediately well functioning market system after deregulation. The reason why actual price development may not be consistent with the theoretical expectation deduced from neoclassical economic theory lies in the inadequate development of the economic system in transition economies in the past. Since the economic sys-

1) With the term advanced transition countries we describe those that joined the EU in May 2004. 
tem of these economies after the Second World War and up to 1991 was based on the principles of socialist economies, there exits a gap in the development of institutions typical for market economies. Furthermore we have to consider that the beginning of the transition period was characterized by a large decrease of GDP growth, rising unemployment and inflation. Consequently there prevails the belief that full liberalisation of prices is not an appropriate solution since growth of prices in the non-tradable sector could endanger the success of stabilisation policies.

Obviously the systemic characteristics of transition economies causes the decision taken by economic policy authorities that, with the beginning of the transition, only those prices would be liberalised where the market system was able to provide price stability and self-regulation. Hence the prices for selected goods and services (especially in the non-tradable sector) remained regulated and were the subject of liberalisation policy in the second stage. However, price liberalisation on those markets did not speed up the competition remarkably, but has led to the distribution of market shares between existing domestic suppliers. Instead of a competitive market there arises a typical oligopoly or perhaps monopoly market structures.

In such circumstances we cannot expect that the price liberalisation will ensure price stability. Perhaps even additional pressure is possible on the growth of prices on the market for goods and services where price control is deregulated, since the initiative for price changes now depends on a small number of producers who face a relatively large amount of demand.

\section{Theoretical Origins of Price Deregulation in Transition Economies}

So far we have discussed the possible systemic reasons why the second stage of price liberalisation has not provided results that are in accordance with the prediction of neoclassical economic theory, which is the recognized paradigmatic source of the European Union development strategy.

But there exist also alternative paradigms of price theory that are in opposition to the neoclassical theory. Most recognized among them is the post-Keynesian theory. The main body of post-Keynesian price models was developed in the 1970s and 1980s (Eichner 1973, Wood 1975, Harcourt and Kenyon 1976, Shapiro 1981, Ong 1981). These price models are based on the assumption that the prices are not aimed at ensuring market clearing, as in neoclassical theory. Particularly they provide the accumulation of financial sources (i.e. the internal financial funds) aimed at financing the future investment. Hence the rising market prices are not necessarily connected to the oligopoly or monopoly power of the supplier, but rather reflect the request for the extension of the new investment in the future.

Following this theoretical point of view, the growth of prices is not a negative sign if higher prices are aimed at financing new investment in new technology that will raise the capital-labour ratio and hence improve the technical efficiency and support the technological progress, spread the production and sales assortment and consequently raise the customer's welfare. This indicates that the final economic impact of price liberalisation can be positive although perfect market competition will not be restored.

There exist few possibilities for restoring the market with perfect competition, also due to the existence of standards and regulations typical for modern economies 
that determine the quality of products and services, in some cases perhaps also the restriction on the allowed amount of production. This presents an important constraining factor that can force the producers to finance new investments aimed at meeting the requirements specified in the standards and regulations about the nature of the product or of the services. In this case, producers need additional funds for financing this investment and for ensuring the profitability of the production or service activity, and they are therefore compelled to raise the prices, although this is not the result of higher market competition.

There exists also an additional important constraint recognized by the post-Keynesian theory that can impede the good functioning of a market mechanism. This is a concession system. In some cases for supplying a specific product or service it is necessary to acquire an appropriate concession first. In this case the selection among the most competitive suppliers does not take place on the market but is realised indirectly, i.e. administratively. This barrier, incorporated in the form of a concession, presents an important obstacle for growth in the number of suppliers, thus raising the market power of present suppliers and lowering the power of demand. Hence, the basic conditions for restoring the well-functioning market mechanisms are not fulfilled.

\section{Specification of the Theoretical Model for Analysing the Impacts of Price Deregulation}

From previous discussion on the systemic and theoretical origins of price deregulation in transition economies it follows that there exist numerous obstacles to both the supply and the demand side of a market for goods and services, that were in the past the object of price regulation. This limits normal functioning of the market mechanism and hence generates possible mechanisms of inertia inflation. These facts raise the importance of price monitoring also after the prices have been liberalised. Following this aim we developed an original model for analysing market outcomes of price deregulation. As we highlighted in the part on theoretical origins of price deregulation in transition, the market outcomes should not be considered only from the perspective of neoclassical theory. In some cases the post-Keynesian theory seems to be more appropriate since many of the characteristics of a transition economy coincide more with a post-Keynesian and not neoclassical economy. According to this, our model combines the neoclassical and post-Keynesian theoretical issues. It consists ${ }^{2}$ of three separate elements: production function, cost function and the parameter that measures the capital-labour ratio.

\section{Production Function}

We use the marginal stochastic frontier production function for analysing the impact of separate production factors (labour and capital) for production, for determining

2) To construct the model we followed the empirical findings from Kamien (in Schwartz 1975, pp. 1-37; Maccini 1981, pp. 609-624; Carlton 1986, pp. 637-658; Hall 1986, pp. 258-338; Blinder 1991, pp. 89-100; Kardaz in Stollery 1998, pp. 593-610; Smolny 2001, pp. 167-184; Smolny 1998, pp. 359-381). 
the returns to scale and for detecting the changes in technical efficiency. As a base framework for specification of the production function we take the findings from Kumbhakar and Lovell (2003, p. 63), Richardson (2002, p. 5), Novak (2003), Aigner et al (1977, pp. 21-37), Battese and Coelli (1995, pp. 247-268), Coelli (1995, pp. 247-268), Caudill et al (1995, pp. 105-111), Green (2000, pp. 394-397), and STATA (2003, pp. 51-61).

Marginal stochastic frontier production functions were first introduced by Aigner, Lovell, and Schmidt (1977) and by Meeusen and van der Broeck (1977). The basic distinguishing characteristics of this group of production functions with respect to the average production function, introduced by Solow (1956) and Swan (1956), lies in the definition of total factor productivity. However, the Solow or Swan (1956) growth accounting framework unrealistically assumes that resources are used efficiently and that total factor productivity growth can only emanate from technological progress.

The marginal stochastic frontier approach relaxes this unrealistic assumption and permits the possibility of technical inefficiency in production (this is exactly the case of the Slovenian economy - see Lesjak and Cohen 2001). The stochastic frontier approach emphasizes the idea of maximality - on the frontier lie all the points that bind the amount of production factors used with the amount of product produced. If there is no inefficiency, the actual point of production lies on the frontier, and otherwise below the frontier. According to this, total factor productivity growth consists of two parts: growth of technological progress and growth of technical efficiency.

The convenient marginal stochastic frontier production function is specified as:

$$
y_{i, t}=\left|f\left(x_{j, i, t}, \beta_{j}\right) \cdot \exp \left(e_{i, t}\right)\right| \xi_{i, t},
$$

where $y_{i, t}$ denotes the amount of the produced product, $x_{j, i, t}$ the amount of production factors used, $\beta_{j}$ the slope coefficient, $e_{i, t}$ stochastic error term and $\xi_{i, t}$ the level of efficiency in production; $i$ denotes industry, $t$ denotes time, and $j$ denotes the production factor.

If there is no technical inefficiency, i.e. if all production factors are optimally allocated, the marginal stochastic frontier production function is consistent with the production frontier $\left(\xi_{i, t}=1\right)$ :

$$
y_{i, t}=f\left(x_{j, i, t}, \beta_{j}\right) \cdot \exp \left(e_{i, t}\right)
$$

Reviewing the existing literature on the estimation of marginal stochastic production function models, we establish that Kalirajan and Shand (1994, p. 167) first developed the methodology aimed towards inference about the impact of efficient use of production factors on the estimated parameters of a marginal stochastic frontier model. They gave proof that the highest magnitude of each random slope coefficient and intercept forms the frontier coefficient of the potential production function:

$$
\begin{aligned}
& \beta_{j}^{*}=\max \left(\beta_{j}\right), \\
& \beta_{j}=(\bar{\beta}+u) \zeta,
\end{aligned}
$$


where $\bar{\beta}$ denotes the mean response coefficient of output with respect to the input, $u$ denotes the random disturbance term, and $\zeta(0 \leq \zeta \leq 1)$ the inefficiency term. Considering (4), it is obvious that the maximum output is determined in a situation where there is no technical inefficiency (consequently $\zeta=1$ ). According to this it follows that rising technical inefficiency (this is illustrated by falling $\zeta$ ). is related with the falling magnitude of the estimated slope coefficient $\beta_{j}$.

So far there remains only the question of how to estimate the stochastic frontier production function, i.e. actual production function, and stochastic frontier alone (i.e. potential production function). For estimating the frontier production function (1) on original data for dependent and explanatory variables we use STATA software that estimates the parameters of the stochastic production function model using the Newton-Raphson algorithm for conducting maximum-likelihood estimates of unknown parameters. STATA software provides estimators for two different specifications of $\zeta_{i, t}$ : for the time-invariant efficiency model (the technical efficiency does not change over time) and for the time-varying efficiency model (in this case the level of technical efficiency can vary over time).

\section{Cost Function}

The second part of the model consists of the cost function. The name can be perhaps misleading since we are not dealing here with a convenient microeconomic cost function but are analysing the cost structure with the purpose of identifying the prevailing factors that determine the dynamic of the production cost. On the basis of this we can make inferences if the growth of costs is predetermined above all exogenously or within the company - perhaps due to the increasing technical inefficiency.

The distinction between internal and external factors of costs is crucial. If the pressure on costs is related to external factors then the raising of market prices is excusable, since it enables the company to subsist on the market. But if the pressure in cost begins from inside of the firm due to the raising of technical inefficiency, the raising of market prices is not excusable. This also indicates that the market mechanism does not function well since it permits raising prices that are not related to financing the new investment aimed towards technological progress.

For this purpose we estimate the following cost function:

$$
z=f\left(v_{k}\right) \cdot \exp (e),
$$

where $z$ denotes total costs, $v$ denotes the $\mathrm{k}$-th constitutional part of total costs, e denotes random error term, and $k$ denotes the cost segment.

\section{Technical Coefficients}

Finally, after realising the characteristics of the production process described by the estimates of a production function and determination of prevailing cost push determinants separated into internal or external, we have to identify if the eventual growth of prices is related to the growth of investment. We measure this on the basis of capital-labour ratio changes over time. In case of an increase in the capitallabour ratio, which is connected to the growth of prices, we can infer about the 
growing investments in new technology that will accelerate the technical efficiency in production and hence lower the pressure of internal factors on the growth of production costs.

But the empirical experience with inflation in Slovenia indicates that price deregulation has not assured the expected positive effect. According to our initial analysis (Žižmond and Novak, 2004), price liberalisation has generated - in contrast to neoclassical economic theory - in the case of the Slovenian economy, the appearance of a new potential source of inertia inflation. We recognize that the new inertial inflation factors take their source from price and income movements in the nontradable sector of the Slovenian economy.

\section{Empirical Analysis of Price Deregulation in Slovenia - the Case of Chimney Sweep Services}

The Slovenian economy belongs to the eight advanced transition economies that joined the EU in May 2004. Among transition countries, Slovenia is treated as a successful economy that has realized good macroeconomic performance (Lesjak and Cohen, 2001, Žižmond and Novak, 2006, pp. 205-225), but is facing some problems regarding the inflation that spilled-over into export competitiveness. The existing analyses (Žižmond and Kračun, 1995, and Žižmond et al, 1999) indicated that the price competitiveness of main export companies in Slovenia decreased and that from 1993 on, the export sector of the Slovenian economy continuously suffered from price competitiveness. These initial findings are supported also by the newest analysis of Bojnec and Novak (2005, pp. 13-14), the authors in their reference analysis recognized a significant decreasing trend of export-to-import price ratios for all industries of the Slovenian economy for the period 1992-2004. As the prices for non-tradable goods and services can constitute also more than $30 \%$ of the cost structure of a tradable good, diminishing export competitiveness of the Slovenian economy can be connected also with the market outcomes on the markets of the nontradable sector, with deregulated process. In the rest of the article we present the in-depth analysis of market outcomes in the case of chimney sweep services.

The prices for chimney sweep services were liberalised in Slovenia in 1997. Altogether, 228 firms registered to provide these services and remained unchanged. At first glance, it seems that there is a sufficient number of firms to restore a market with perfect competition. But one of the basic characteristics of the chimney sweep services market in Slovenia is the concession system. Each firm that is to provide the services has to acquire a licence, and this not at the level of national economy but at the level of municipalities. There are more than 200 municipalities that approximately coincide with the number of registered suppliers. Exactly this coincidence in number of suppliers with the number of municipalities, that in the broader sense determine the number of concessions, led us to the thesis that this supply side constraint negatively affects the outcomes of the deregulated chimneysweep services market. We proceeded with an empirical proof of this thesis using our original model as described previously in Section 3.

Although the prices for chimney sweep services were deregulated in 1997, up to 2001 the evidence of price monitoring does not allow us to conduct a complete empirical analysis according to our model. Therefore we restricted the analysis to 
the period 2001-2003. Combining the three-year period with 228 units into the panel data system brings us 684 observations that meet the theoretically postulated criteria for conducting relevant statistical tests.

The data on market prices were collected using the questionnaire that was sent to the enterprises. Since the assortment of services was not homogeneous among different suppliers, we selected the following main services that were included into the sortiment of each enterprise:

- chimney stack cleaning,

- up to 60 kilowatt stove cleaning,

- over 60 kilowatt stove and cauldron cleaning,

- smoke emission measurement,

- professional control examination.

The data on value added, which measure the amount of production, number of employed workers and physical capital (tangible fixed assets), that express the amount of used production factors and the data on the labour and capital cost were collected from the Agency of the Republic of Slovenia for Public Legal Records and Related Services. Using the specified data we conducted an analysis on the economic impact of price deregulation. First, we analysed the level and the dynamic of prices; second, we estimated the parameters of the production function; third, the cost function was analysed and, finally, the technical coefficients, defined as capital-labour ratio, were obtained.

\section{Price Level and Its Dynamics}

As earlier mentioned, the prices for chimney sweep services were liberalised in 1997. The specific feature of these services was that each individual supplier was obliged to acquire a concession for separate municipalities that allow him to perform the services. Therefore the selection of suppliers is not realized on the market; the suppliers are selected in the administrative way. Within such supply constraints, where other potential suppliers are dropped out of the market, the price mechanism cannot work well - because the market failure arises on the supply side, the additional pressure on the price movements becomes possible. But the acquired concession also presents the individual supplier with a form of obligation to realise the services even though the consumers have already paid for the services.

Using the questionnaires we collected the data for five main groups of chimney services and calculated the average price level for separate years from 2001-2003 and additionally the chain- and cumulative growth rate (Table 1).

Following the results summarised in Table 1, we can recognise that the price movements were quite heterogeneous. From 2001 till 2002, the price growth rate was the same for all selected kinds of services and amounts to approximately $9 \%$, while the price movements after 2002 were much different. The prices for professional control examination failed by almost $30 \%$, while the prices for cleaning the stove of over 60 kilowatts and the cleaning of the cauldron rose by more than $160 \%$, additionally also the prices for chimney stack cleaning were noticeably raised. We can, therefore, conclude that generally the cumulative growth of prices for selected services amounts to about $60 \%$, thus exceeding by 6 -times the value of the cumulative growth of producer prices or consumer prices (the cumulative produce price 
Table 1

Price Level (in SIT) and Its Dynamics for Selected Chimney Sweep Services for the Period 2001-2003

\begin{tabular}{|l|r|r|r|}
\hline Kind of services/year & $\mathbf{2 0 0 1}$ & $\mathbf{2 0 0 2}$ & $\mathbf{2 0 0 3}$ \\
\hline up to 60 kilowatt stove cleaning & 1847 & 2012 & 1945 \\
over 60 kilowatt stove and cauldron cleaning & 896 & 976 & 2401 \\
chimney stack cleaning & 2335 & 2543 & 3536 \\
professional control examination & 16862 & 18364 & 13643 \\
smoke emission measurement & 5594.5 & 6093 & 8847 \\
\hline Kind of services/growth rate coefficient & $\mathbf{2 0 0 2 / 2 0 0 1}$ & $\mathbf{2 0 0 3 / 2 0 0 2}$ & $\mathbf{2 0 0 3 / 2 0 0 1}$ \\
for the period & & & \\
\hline up to 60 kilowatt stove cleaning & 1.0893 & 0.9667 & 1.0531 \\
over 60 kilowatt stove and cauldron cleaning & 1.0893 & 2.4600 & 2.6797 \\
chimney stack cleaning & 1.0891 & 1.3905 & 1.5143 \\
professional control examination & 1.0891 & 0.7429 & 0.8091 \\
smoke emission measurement & 1.0890 & 1.4520 & 1.5812 \\
\hline
\end{tabular}

Note: The average price level for separate services was calculated as the arithmetic mean of 120 observations per period - note that from 228 enterprises, 120 of them provided sufficient data that were included into the database. In some enterprises the growth of prices was not as high as our end estimates indicated, and that there arise also great disparities in price levels and their dynamic among separate municipalities, since for each municipality a different concession has to be acquired. Consequently there are cases where the same supplier charges different prices for each type of services in different municipalities. Therefore the obtained dynamics and level of average prices is subject to large regional disparities in prices levels and their dynamics. The reader should be aware of this problem when analysing our results.

Source: original data acquired by using a questionnaire

index (PPI) for the period 2001-2003 amounts to 107.7 and the cumulative index for consumer prices (CPI) amounts to 113.5 for the same time period).

\subsection{Estimates of Production Function and Technical Efficiency Level}

In order to infer about the nature of production process, i.e. service performances, we estimated the following Cobb-Douglas specification of a marginal stochastic frontier production function:

$$
y_{i, t}=\left[f\left(x_{1_{i, t}}, x_{2_{i, t}}\right) \cdot \exp \left(e_{i, t}\right)\right] \xi_{i t},
$$

where:

$y_{i, t}$ measures the amount of production measured as real value added in 2000 constant prices (CPI was used as deflator),

$X_{1, t}$ measures the amount of production factor physical capital expressed as tangible fixed assets in billions of SIT in 2000 constant prices (PPI was used as deflator) real value added in 2000 constant prices, $x_{2_{i, t}}$ measures the amount of production factor labour expressed as the number of employees, 
$e_{i, t}$ measures the stochastic disturbances, and

$\zeta_{i, t}$ measures the systematic disturbance, i.e. efficiency level (the estimate of efficiency change over time is given by the magnitude of parameter $\eta$ ).

Obtained estimates are reported in Table 2.

Table 2

Estimates of Production Function Parameters for Chimney Sweep Services for the Period 2001-2003

\begin{tabular}{|c|c|}
\hline Parameter & Magnitude \\
\hline Wald $\chi^{2}$ & 414.93 \\
& $(0.000)$ \\
$\beta_{1}$ & 0.365 \\
$\beta_{2}$ & $(0.000)$ \\
& 0.566 \\
$\eta$ & $(0.000)$ \\
& -0.152 \\
& $(0.000)$ \\
\hline
\end{tabular}

Symbols:

$\beta_{1}$ - magnitude of the elasticity coefficient that measures the percentage change in amount of output induced by the $1 \%$ growth of physical capital,

$\beta_{2}$ - magnitude of the elasticity coefficient that measures the percentage change in amount of output induced by the $1 \%$ growth of employed workers,

$\eta$ - magnitude of the efficiency parameter that measures the change of efficiency level over time.

Note: In round brackets there are reported the exact levels of significance (p-value) for separate estimated parameters.

Following the obtained results we establish that decreasing returns of scale are significant for chimney sweep services as the $1 \%$ increase of production factor labour induces a $0.365 \%$ increase in output, the $1 \%$ increase of production factor capital induces a $0.566 \%$ increase in output, hence the joint $1 \%$ increase in both production factors induces a 0.931 increase in output measured in terms of real value added. The estimated magnitude of the parameter that measures the technical efficiency parameter through time indicated a moderate growth in technical efficiency for the period 2001-2003. Following our theoretical point of view this can be connected with the absence of a sufficient degree of competition pressure on the market.

\section{Estimates of Cost Function}

For analysing the nature of the production cost, we estimate the following cost function:

$$
z_{i, t}=f\left(v_{1, t}, v_{2_{i, t}}, v_{2_{i, t}}\right) \cdot \exp \left(e_{i, t}\right)
$$

where:

$z_{i, t}$ measures the total production costs for $\mathrm{i}$-th enterprise in $\mathrm{t}$-th time period, 
$V_{1, i, t}$ measures the costs of products and services intended for intermediate consumption,

$V_{2_{i, t}}$ measures the costs of labour,

$V_{3_{i, t}}$ measures costs of capital,

$e_{i, t}$ is a stochastic error term,

$i$ indicates enterprises included, and

$t$ indicates time period.

The estimates are reported in Table 3.

Table 3

Estimates of Cost Function Parameters for Chimney Sweep Services for the Period 2001-2003

\begin{tabular}{|c|c|}
\hline Parameter & Magnitude \\
\hline$R^{2}$ & 0.969 \\
& $(0.000)$ \\
$\beta_{1}$ & 0.291 \\
& $(0.000)$ \\
$\beta_{2}$ & 0.585 \\
$\beta_{3}$ & $(0.000)$ \\
& 0.031 \\
\end{tabular}

Symbols:

$\beta_{1}$ - magnitude of the elasticity coefficient that measures the percentage change in production costs induced by the $1 \%$ growth of costs of intermediate products and services,

$\beta_{2}$ - magnitude of the elasticity coefficient that measure the percentage change in production costs induced by the $1 \%$ growth of labour costs,

$\beta_{3}$ - magnitude of the elasticity coefficient that measures the percentage change in production costs induced by the $1 \%$ growth capital costs.

According to the estimates of the cost function (summarized in Table 3) we conclude that the growth of production cost was mainly determined on the basis of the external factors, especially from the labour costs and costs of intermediate product and services. Labour costs are recognized as the most important factor in the cost structure, since the $1 \%$ increase in wages induces a $0.585 \%$ increase in total cost, and the $1 \%$ increase in costs of capital induces only a $0.031 \%$ increase in total costs, while the $1 \%$ growth of costs of products and services intended for intermediate consumption induces a $0.291 \%$ growth of total costs. The joint $1 \%$ growth of all three separate parts of costs induces the less than $1 \%$ growth in total cost, which is congruent with otherwise moderate growth of technical efficiency. This indicates that the enterprises did not transmit the whole increase in costs into the growth of the market prices.

\section{Capital-Labour Ratios}

In 2003, compared to 2001, the level of capital-labour ratio was more than 1.5-times greater than the capital-labour ratio in the initial year (2001). In this case, the 
cumulative growth of capital labour ratio amounted to $63.63 \%$ (see Table 4) and was predominately determined by the growth of capital $(44.12 \%)$ rather than the growth of labour (13.54\%).

Table 4

\section{Estimates of Capital-Labour Ratios for Chimney Sweep Services for the Period 2001-2003}

\begin{tabular}{|l|c|}
\hline Parameter & Magnitude \\
\hline$K / L_{2001}$ & 265.2963 \\
$K / L_{2002}$ & 354.2779 \\
$K / L_{2003}$ & 434.1173 \\
$K / L_{2002}$ & 1.3354 \\
\hline$K / L_{2001}$ & 1.2254 \\
$K / L_{2003}$ & \\
\hline$K / L_{2002}$ & 1.6363 \\
\hline$K / L_{2003}$ & \\
\hline$K / L_{2001}$ & \\
\hline
\end{tabular}

Symbols:

$K$ - physical capital

$L-$ labour

The fast growth of market prices (cumulative from 2001 till 2003 by more than $60 \%$ ) and capital-labour ratios (by more than $50 \%$ in the same time period) indicate that the new investments were financed on the basis of mark-up price levels that consequently lead to the growth of market prices. But for the observed period we cannot establish that realised investments are related to the growth of technical efficiency, since it remains trivial.

\section{Conclusions and Policy Implications}

In this article we focus on the impact of price liberalisation on the functioning of market mechanism for chimney sweep services in the Slovenian economy.

The considered prices were liberated in 1997, but because of constraints in the responsive time series data we have restricted our analysis to the period 2001-2003. For this period we recognize a high growth of prices for selected chimney sweep services, amounting cumulatively to about $60 \%$. The observed cumulative growth rate of prices for chimney sweep services was therefore more than 6-times greater than the cumulative growth of producer prices in the economy. We consider that the large growth of prices is the consequence of significant supply side imperfection, since the selection among suppliers that could perform the chimney sweep services is based on the concession system at the municipality level. That influences the decrease of competition pressure on the market and strengthens the market power of the existing market leaders.

Otherwise, the cumulative growth of capital-labour ratio was fast and is comparable with cumulative growth of prices, but we cannot uniformly interpret this as 
the result of rising market competition among existing suppliers, since for all suppliers the slow growth of technical efficiency is significant. Two possible explanations exist: first, the competition among existing suppliers is sufficient and impose pressure on them to make new investments aimed at productivity growth, but the adjustment process is quite long, therefore the slow growth of technical efficiency is only temporary. Second, there is no sufficient degree of market competition, and the existing suppliers are forced to conduct new investments in modern equipment because of different regulations stipulated by the government.

If we sum up all four dimensions of our analysis (price movements, technical efficiency changes, cost function properties and dynamic of capital-labour ratio), we realise that the chimney sweep services market has not developed itself into a well functioning system since the price liberalisation.

We estimate that this is because of significant supply side distortions due to the selection of suppliers on the basis of the concession system. Hence there is an absence of potential to impede the competition growth on the market. Therefore, the main policy implication is to omit the concession system and allow the demandsupply price mechanism to conduct the selection among the suppliers. This should lead to higher market competition and hence to a reduction of the price growth. If we consider that there exists a sufficient number of potential enterprises aimed at conducting services, then the omission of the concession system would rapidly restore the well functioning market system. We expect that this would not lead to a large reduction in profit of existing companies, although that price dynamics would be much slower - namely the negative effect of slower price growth would be replaced by higher growth in technical efficiency.

We conclude that restoration of the well-functioning market mechanism for chimney sweep services would be possible if the concession system were removed.

\section{References}

Aigner, D.J., Lovell, C.A.K., Schmidt, P. (1977), "Formulation and Estimation of Stochastic Frontier Production Function Models." Journal of Econometrics, 6(1), pp. 21-37.

Battese, G.E., Coelli, T.J. (1995), "A Model for Technical Inefficiency Effects in a Stochastic Frontier Production for Panel Data." Empirical Economics, 20, pp. 325-332.

Blinder, A.S. (1991), "Why are Prices Sticky?" American Economic Review. 81(2), pp. 89-96.

Bojnec, Š., Novak, M. (2005), "Metodologija za ugotavljanje konkurenčnih prednosti in pozicioniranje sektorjev slovenskega gospodarstva po konkurenčnih prednostih blagovne menjave." IB revija, 39(1-2), pp. 4-25.

Carlton, D.W. (1986), “The Rigidity of Prices." American Economic Review, 76(4), pp. 637-658.

Caudill, S.B., Ford, J.M., Groopper, D.M. (1995), "Frontier Estimation and Firm - Specific Inefficiency Measures in the Presence of Heteroskedasticity." Journal of Business and Economic Statistics, 13(1), pp. 105-111.

Coelli, T.J. (1995), "Estimators and Hypothesis Test for a Stochastic Frontier Function: A Monte Carlo Analysis." Journal of Productivity Analysis, 6(4), pp. 247-268.

Eichner, A.S. (1973), "A Theory of Determination of the Mark-Up under Oligopoly." Economic Journal, 83(322), pp. 1184-2000.

Green H.W. (2000), Econometric Analysis. New York: Prentice Hall International, Inc.

Hall, R. E. (1986), "Market Structure and Macroeconomic Fluctuations." Brookings Papers on Economic Activity, 1986(2), pp. 285-338. 
Harcourt, G.C., Kenyon, P. (1976), "Pricing and Investment Decision”. Kyklos, 29(3), pp. 449-477.

Kalirajan, K.P., Shand, R.T. (1994), Economics in Disequilibrium: An Approach from the Frontier. Bangalore: Macmillan.

Kamien, M.I., Schwartz, N.L. (1975), "Market Structure and Innovation: A Survey." Journal of Economic Literature, 13(1), pp. 1-37.

Kardaz, S.W., Stollery, K.R. (1998), "Determinants of Domestic and Import Prices in Canadian Manufacturing Industries." Empirical Economics, 23(4), pp. 593-610.

Kumbhakar, S.C., Lovell, A.C.K. (2003), Stochastic Frontier Analysis. Cambridge: University Press.

Lesjak. D., Cohen, E. (2001), "Transitioning the Slovenian Economy." Eastern European Economics, 39(2), pp. 49-71.

Maccini, L.J. (1981), "On the Theory of the Firm Underlying Empirical Models of Aggregate Price Behavior." International Economic Review, 22(3), pp. 609-624.

Meeusen, W., van den Broek, J. (1977), "Efficiency Estimation from Cobb-Douglas Production Function with Composed Error." International Economic Review, 18(2), pp. 435-444.

Novak, M. (2003), Analiza narave rasti slovenskega gospodarstva. Koper: UP Fakulteta za management Koper.

Ong, N.P. (1981), "Target Pricing, Competition, and Growth." Journal of Post Keynesian Economics, 3(1), pp. 101-116.

Richardson, S. (2002), "Efficiency Estimation Using the Stochastic Production Frontier Approach." Department of Applied and International Economics Discussion Paper, No. 02.05, pp. 2-21.

Shapiro, N. (1981), "Pricing and the Growth of the Firm." Journal of Post Keynesian Economics, 3(1), pp. 85-100.

Smolny, W. (1998), "Innovations, Prices and Employment - A Theoretical Model and an Empirical Application for West German Manufacturing Firms." Journal of Industrial Economics, 46(3), pp. 359-381.

Smolny, W. (2001), "Price Adjustment at the Firm Level: A Theoretical and Empirical Analysis." Small Business Economics, 20(3), pp. 167-184.

Solow, R. (1956), "A Contribution to the Theory of Economic Growth." Quarterly Journal of Economics, 70(1), pp. 65-94.

STATA (2003), Stata Cross-Sectional Time-Series Reference Mannual. New York: Stata Press Publication.

Swan, T.W. (1956), "Economic Growth and Capital Accumulation." The Economic Record, 32, November, pp. 334-361.

Vives, X. (1999), Oligopoly Pricing. Old Ideas and New Tools. Cambridge: MIT Press.

Wood, A. (1975), A Theory of Profits. Cambridge: Cambridge University Press.

Žižmond, E., Kračun, D. (1995), "Tranzicija in censke disparitete." Bilten EDP, 18(4), pp. 23-38.

Žižmond, E., Kračun, D., Bekő, J., Jagrič, T. (1999), "Slovenija in Avstrija - ravni cen in plač." Bilten EDP, 22(1), pp. 1-78.

Žižmond, E., Novak, M. (2004), Model spremljanja dereguliranih cen v nemenjalnem sektorju slovenskega gospodarstva. Koper: UP Fakulteta za management Koper.

Žižmond, E., Novak, M. (2006), "Sectoral Reallocation of Labor as a Limit on Total Factor Productivity Growth in Slovenia." Post-Communist Economies, 18(2), pp. 205-225. 